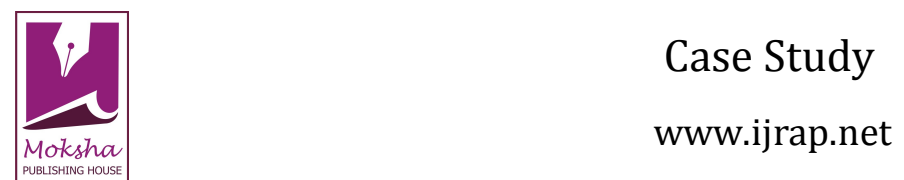

\title{
SUCCESSFUL APPLICATION OF PURGATION THERAPY WITH AYURVEDIC HERBO-MINERAL FORMULATIONS IN MANAGEMENT OF ASCITES: A CASE STUDY
} Bendale Yogesh Narayan ${ }^{1 *}$, Bendale Vineeta Yogesh ${ }^{2}$, Kadam Avinash Pandurang ${ }^{3}$, Birari-Gawande Poonam Kantilal ${ }^{4}$

${ }^{1}$ Director, Ayurved Rasayani, Pune, Maharashatra, India

${ }^{2}$ Managing Director, Ayurved Rasayani, Pune, Maharashatra, India

${ }^{3}$ Research Associate, Ayurved Rasayani, Pune, Maharashtra, India

${ }^{4}$ Assistant Research Physician, Ayurved Rasayani, Pune, Maharashtra, India

Received on: 29/10/15 Revised on: 07/12/15 Accepted on: 04/01/16

\author{
*Corresponding author \\ E-mail: drbendale@gmail.com
}

DOI: $10.7897 / 2277-4343.07253$

\begin{abstract}
Ascites is the commonest complication of liver cirrhosis with poor prognosis \& reduced survival rate. The aetiology of Ascites in cirrhosis is multifactorial and the efficacy of currently available treatments is still unsatisfactory. Ayurveda recommends Purgation therapy for treatment of Ascites. Herein, we present a case of 36 years' patient of grade 3 Ascites with alcoholic liver cirrhosis \& jaundice treated successfully with purgation therapy and Ayurveda formulations. Within one month of starting the therapy patient showed significant improvement in the form of clinical, biochemical\& radiological parameters.
\end{abstract}

Keywords: Ascites, Purgation therapy, Ayurveda, Liver disorders

\section{INTRODUCTION}

Ascites is defined as a condition of abnormal accumulation of fluid in the peritoneal cavity. It usually results from hyperdyanamic circulatory dysfunction where the retention of sodium \& water is associated with the activation of the sympathetic \& rennin-angiotensin aldosterone systems ${ }^{1}$ Liver cirrhosis is the most common cause of ascites development with more than $80 \%$ of ascites developing in patients with liver cirrhosis. Mortality rate has been noted in $15 \%$ patients in the $1^{\text {st }}$ year \& $44 \%$ in the 5 years after its diagnosis. ${ }^{2}$ Hepatocellular deaths, regeneration and progressive fibrosis are the three major pathological mechanism contributes to create cirrhosis ${ }^{3}$. The conventional treatment options are limited and are mainly directed towards prevention of further liver damage and treatment of complications. Ayurveda therapies are seen to be beneficial to patients of liver cirrhosis. Ayurveda has mentioned several formulations which acts as hepatoprotective and are known to offer considerable protection against further liver damage. Ayurveda has advised purgation therapy for treatment of ascites. In this present case the patient responded very positively to combination of Purgation therapy and various Ayurvedic hepatoprotective and Rasayana formulations.

\section{Case Presentation}

Here, we present a case of Ascites due to alcoholic liver cirrhosis. A 36years old male patient presented to us with complaining of increased abdominal distension, abdominal bloating, shortness in breathing recurrent jaundice, loss of appetite and pitting edema. He was also suffering from loose motions for 10 to 12 times per day, nausea, intermittently vomiting, acidity for six months. He had lost $22 \mathrm{~kg}$ weight in six months. He had been suffered three times from Jaundice in six months.
His USG-Abdomen/pelvis dated 19/8/14 showed Bright \& coarse echo texture of liver with shrunken right lobe suggestive of changes of cirrhosis, gross ascites with bilateral pleural effusion. His base line Liver function test showed total bilirubin level of 6.97 (Table 2) and urine examination revealed presence of bile salt and bile pigment in his urine test.

On examination patients general condition was stable with pallor and icterus. The abdomen was distended with bulging of flanks. Veins on the wall appeared prominent with shifting dullness and bipedal edema. Abdominal girth at umbilicus was $102 \mathrm{~cm}$ and weight was $61.1 \mathrm{~kg}$. Patient was diagnosed with Grade III Ascites due to liver cirrhosis, with Alcoholic hepatitis. We started treatment on 18/8/14 with purgation therapy and classical Ayurvedic formulations like Agnitundi Ras, Sutshekhar Ras, Kamdudha Ras, etc. (Table 1) and proprietary medicines like Vrushya rasayana (Main ingredient-Ashwagandha). Daily purgation was given by Ichhabhedi ras in the morning and during treatment period patient was advised only take cow milk as his digestive power was less.

\section{RESULTS}

Within one month of starting the treatment patient showed excellent therapeutic response. Within fifteen days' patient's appetite and general condition improved and pedal oedema decreased considerably. We repeated USG-Abdomen + Pelvis on (29/9/14 — 40 days after starting therapy) which showed normal findings with no ascites. His follow up abdominal girth was $87 \mathrm{~cm}$ and also his total bilirubin levels get decreased to 1.21 (Table 2). He is completely asymptomatic and his biochemical parameters were within normal range. 
Table 1: Treatment chart

\begin{tabular}{|c|c|c|c|}
\hline Drug name & Dose & Frequency & Anupan \\
\hline Ichabhedi Ras & $500 \mathrm{mg}$ & OD & warm water \\
\hline Agnitundi Ras & $125 \mathrm{mg}$ & OD & Lime juice \\
\hline Aarogyawardhini & $500 \mathrm{mg}$ & BD & Warm water \\
\hline Tapyadi Loha & $250 \mathrm{mg}$ & BD & Warm water \\
\hline Sutshekhar & $10 \mathrm{mg}$ & BD & Warm water \\
\hline Prawal Panchamrut & $250 \mathrm{mg}$ & BD & Warm water \\
\hline Kamdudha Ras & $250 \mathrm{mg}$ & BD & Warm water \\
\hline Powder Of Gokshur & $400 \mathrm{mg}$ & BD & Warm water \\
\hline Powder Of Kawachbeej & $400 \mathrm{mg}$ & BD & Warm water \\
\hline Vrushya Rasayan & $250 \mathrm{mg}$ & HS & Honey \\
\hline
\end{tabular}

Table 2: Results of liver function test

\begin{tabular}{|c|c|c|}
\hline LFT/DATE & Before treatment (16//8/14) & After Treatment (1/10/14) \\
\hline Total Protein (g/dL) & 7.1 & 7.6 \\
\hline Sr.Albumin (g/dL) & 2.1 & 3.2 \\
\hline Sr.Globulin (g/dL) & 5.0 & 4.40 \\
\hline Total Bilirubin (mg/dL) & 6.97 & 1.21 \\
\hline Direct Bilirubin (mg/dL) & 5.39 & 0.76 \\
\hline Indirect Bilirubin (mg/dL) & 1.58 & 0.45 \\
\hline SGPT (IU/Lt) & 35 & 27 \\
\hline SGOT (IU/Lt) & 111 & 70 \\
\hline Alkaline Phosphate (IU/Lt) & 134 & 111 \\
\hline
\end{tabular}

\section{DISCUSSION}

In Ayurveda purgation therapy is a unique concept used in Udar vyadhi where pathological factors are expelled from body through daily purgation. ${ }^{5}$

We used this concept in treating this patient. Patient was given purgation by administration of a classical Ayurvedic formulation Ichabhedi $\mathrm{Ras}^{6}$. Jaypal beej (Croton Tiglium) is one of the important content of Ichhabhedi ras and it has been reported to have purgative, analgesic and anti-microbial properties. ${ }^{7}$ It exhibits its purgative action by increasing the gut motility partially via muscarinic receptor activation. It might be act by diminishing reabsorption of water from intestine, by stimulating nerves in small \& large intestines resulting in increased motility. ${ }^{7}$ According to results we got in this patient, it is possible that it might be creating negative osmotic pressure thereby modifying the fluid dynamics of mucosal cell and lumen by creating negative osmotic pressure.

The Ayurvedic formulations selected for this case were planned considering aims to protect hepatocytes from further damage and to stop formation of fibrosis, inflammation, and formulations were also selected so as to improve liver function. For all this purpose we used herbomineral compounds (Table 1) which have action on digestive and circulatory systems. The rationale of selection of formulations was based on principle of Ayurveda therapeutics like improving the agni and administering Rasayana drugs to offer protection to rasa and raktavaha, udakwaha strotas.

During treatment period patient was advised only take cow milk as according to Ayurvedic text cow milk is equal to amrut and it is very useful in critical and chronic illness cow milk possess various properties like ojowardhak (increased immunity), Dhatuwardhak (nourishes body tissues,), balya (improved strength), increases life expectancy, vrushya (natural aphrodisiac) best rasayana (good rejuvenator $)^{7,8}$

We got appreciable results in the form of relief from symptoms, decreased bipedal oedema, increase appetite and energy levels.
It shows potential of purgation therapy in clearing Ascetic fluid collection.

In case of Ascites, main goal is to improve the quality of life with prerequisite of maintaining a stable hemodynamic condition. Unfortunately, even with diuretic use or salt restricted diet cannot prevent Ascites formation in advanced liver cirrhosis so it is customary to find another approach to control Ascites formation.

We treat patient through Rasayana and Purgation therapy by using hepatoprotective drugs which gave excellent results in the form of clinical, biochemical and radiological findings. In diet only cow milk and Purgation can play a definite role in treating such patients but to prove this action randomised controlled trials should be performed.

\section{CONCLUSION}

Ascites in presence of liver cirrhosis remains a challenge in treatment. The currently available therapies do not provide a satisfactory response. Through this case report we would like to demonstrate that the line of treatment of Ascites mentioned in Ayurveda texts certainly has a great potential. Our observations in treating similar cases show that this therapy has an excellent safety and tolerability and hence it can be utilised in treatment of Ascites. Further studies to systematically explore its tolerability, safety, efficacy and mechanism of action are required which will help to incorporate these therapies in standard line of treatment in treating patients with Ascites.

\section{REFERENCES}

1. Raveendran SR, Kiruthika A, Vaishali S. Ascites in Cirrhosis: A Review of Pathophysiology, Diagnosis and Treatment. Research Journal of Pharmaceutical Biological and Chemical Sciences 2014;5(5):12-23.

2. Shao-Jung Hsu, Hui-Chun Huang.Management of ascites in patients with liver cirrhosis: Recent evidence and controversies. Journal of the Chinese Medical Association 2013;76:123-130.

3. Chauhan Prerna et al. Liver disorders.Int. J.Res. Ayurveda Pharm.2011.2 (2):369-374. 
4. Prof. Ravidatta Tripathi, Charaka Samhita, Varanasi. 2007 Ed, Chaukhamba Prakashana siddhisthana 1/17,879.

5. Shri Govind Dasji. Bhaishjya ratnawali Udarrogadhikar 13105.

6. Shilpa Patil. A Critical review on up wish with special reference to their therapeutics. J Bio Sci Opin. 2014;2 (2):196-202.

7. Prof. Ravidatta Tripathi, Charak Samhita Varanasi .2007 Editor Chaukhamba Prakashana, Chikitsastahan1.3/52-55.

8. Prof. RavidattaTripathi, Charak sanhita Varanasi .2007 Editor Chaukhamba Prakashana, Sutrasthan 27/217-218.

\section{Cite this article as:}

Bendale Yogesh Narayan, Bendale Vineeta Yogesh, Kadam Avinash Pandurang, Birari-Gawande Poonam Kantilal. Successful application of purgation therapy with Ayurvedic herbo-mineral formulations in management of ascites: A case study. Int. J. Res. Ayurveda Pharm. Mar - Apr 2016;7(2):42-44 http://dx.doi.org/10.7897/2277-4343.07253

Source of support: Nil, Conflict of interest: None Declared

Disclaimer: IJRAP is solely owned by Moksha Publishing House - A non-profit publishing house, dedicated to publish quality research, while every effort has been taken to verify the accuracy of the content published in our Journal. IJRAP cannot accept any responsibility or liability for the site content and articles published. The views expressed in articles by our contributing authors are not necessarily those of IJRAP editor or editorial board members. 